\title{
"Mend the Hold" and Erie: Why an Obscure Contracts Doctrine Should Control in Federal Diversity Cases
}

\author{
Robert H. Sitkoff
}

Suppose an insurance company rejects a policyholder's claim, giving a specific reason for the denial in a declination letter. Convinced that this reason is not valid, the policyholder sues the company for breach of contract. Should a court permit the insurance company to raise defenses not based on the specific reason given in the declination letter? ${ }^{1}$ Under one version of the common law "mend the hold" doctrine, the answer is no. Furthermore, despite the procedural flavor of the rule, under modern Erie analysis the mend the hold doctrine represents the sort of state prerogative that federal courts sitting in diversity must respect.

The phrase "mend the hold" comes from nineteenth century wrestling parlance where it meant "get a better grip (hold) on your opponent." Its first appearance in a judicial opinion was in a nineteenth century Supreme Court decision that refused a party in a contract suit the right to defend its nonperformance with a defense that it had not raised before the close of evidence. ${ }^{3}$ Since then, the doctrine has evolved into two modern forms. Under the Illinois (minority) version of the rule, absent a good faith justification for a change in position, a defendant in a breach of contract action is confined to the first defense raised once the litigation is underway. ${ }^{4}$ In contrast, the majority version of the doc-

$\dagger$ B.A. 1996, The University of Virginia; J.D. Candidate 1999, The University of Chicago.

1 This hypothetical draws on Kevin Walsh and Michele Levy, "Mend the Hold"-An Old Doctrine May Be A Policyholder's Best Friend, The Metropolitan Corporate Counsel 13 (Sept 1995).

2 Harbor Insurance Co $v$ Continental Bank Corp, 922 F2d 357, 362 (7th Cir 1990).

- Railway Co $v$ McCarthy, 96 US 258, 267-68 (1877) ("Where a party gives a reason for his conduct and decision touching any thing involved in a controversy, he cannot, after litigation has begun, change his ground, and put his conduct upon another and a different consideration. He is not permitted thus to mend his hold. He is estopped from doing it by a settled principle of law.") (emphasis added).

4 Israel v National Canada Corp, 276 Ill App 3d 454, 462, 658 NE2d 1184, 1191 (1996) (holding that a party must stand by the first defense raised once litigation has begun). See also Cole Taylor Bank $v$ Truck Insurance Exchange, 1994 US Dist LEXIS 3705, *14-15 (N D III) ("As pre-trial discovery revealed an alleged basis for the defenses of waiver and estoppel, this Court holds that application of the doctrine of 'mend the hold' to 
trine limits the nonperforming party's potential defenses to those based on the explanation given at the time of the nonperformance. ${ }^{5}$

The majority formulation has been applied especially to insurance contracts, ${ }^{6}$ has been discussed as a rule of real estate brokerage contracts, ${ }^{7}$ and a closely related version has been codified in the Uniform Commercial Code. ${ }^{8}$ Yet despite the doctrine's apparently wide reach, modern contracts scholars have for the most part overlooked it. ${ }^{9}$

Because mend the hold is a hybrid of a substantive rule of contract law and a procedural rule governing pleading, it is unclear whether federal courts should apply mend the hold in diversity cases. Application of the doctrine would make rigid "the system of pleading that the Federal Rules of Civil Procedure seek to make supple." Traditional analysis under Erie Railroad Co $v$

bar the Defendant's assertion of waiver and estoppel is not appropriate.").

- See, for example, Heidner v Hewitt Chevrolet Co, 166 Kan 11, 14-15, 199 P2d 481, 484 (1948) ("Since the defendant here, before litigation was commenced, gave only as its reason for nonperformance a ground which was inadequate, it could not, after suit was filed, 'mend its hold' and rely upon other and different defenses. It was limited in the trial to the single defense it asserted at the time of breach.").

- See, for example, Erickson v Carhart, 1996 Neb App LEXIS 234, *10-11 ("The rule is that an insurer that gives one reason for its conduct and decision as to a matter of controversy cannot, after litigation has begun, defend upon another and different ground."); Hamlin v Mutual Life Insurance Co, $145 \mathrm{Vt} 264,267,487$ A2d 159, 161 (1984) (referring to the "insurance defense waiver rule").

' See, for example, Weldon v Lashley, $214 \mathrm{Ga}$ 99, 103, 103 SE2d 385, 388 (1958) ("If this was the sole ground of objection assigned by the owner at the time of such refusal, other grounds of objection then known to her were waived, and would not avail her as a defense to an action for the commission.") (internal quotations and citations omitted).

${ }^{8}$ UCC $\$ 2-605$ (ALI 1994) ("Waiver of Buyer's Objections by Failure to Particularize"). See text accompanying note 89 .

- Aside from the occasional reference to the problem of a posteriori justifications, see Comment, Remedies for Total Breach of Contract under the Uniform Revised Sales Act, 57 Yale L J 1360, 1363 (1948), the explicit treatment of the doctrine in journal commentary is cursory at best. See, for example, Howard Ende, Eugene R. Anderson, and Susannah Crego, Liability Insurance: A Primer for College and University Counsel, $23 \mathrm{~J}$ Coll \& Univ I 609, 710-11 (1997) (outlining the doctrine in six paragraphs). Modern casebooks and treatises, moreover, are silent on the topic. Neither "mend the hold" nor Railway Co $v$ McCarthy (the first mend the hold case) appear in the indices or tables of cases of the following: John D. Calamari and Joseph M. Perillo, Contracts 997, 1038, 1041 (West 3d ed 1987); John P. Dawson, William Burnett Harvey, and Stanley D. Henderson, Cases and Comment on Contracts xli, 1027-28 (Foundation 6th ed 1993); E. Allan Farnsworth, Farnsworth on Contracts 741 (Little, Brown 1990); Charles L. Knapp and Nathan M. Crystal, Problems in Contract Law: Cases and Materials 1277, 1315 (Little, Brown 3d ed 1993). Williston on Contracts does cite McCarthy, but the discussion is under the head of "equitable estoppel," not mend the hold. Richard A. Lord, 4 Williston on Contracts § 8:3 at $35 \mathrm{n} 7$ (Law Co-op 4th ed 1992). On the relationship between equitable estoppel, McCarthy, and mend the hold, see Part I.

${ }^{10}$ Harbor Insurance, $922 \mathrm{~F} 2 \mathrm{~d}$ at 364. 
Tompkins, ${ }^{11}$ provides no clear answer. To the extent that the rule represents a state's attempt to channel prelitigation behavior and to make it easier to win breach of contract cases, it should control in federal diversity suits. ${ }^{12}$ But at the same time, when a state rule conflicts with a Federal Rule of Civil Procedure, the state rule must yield. ${ }^{13}$ Thus, it is not surprising that when confronted with mend the hold arguments, federal courts have come to inconsistent conclusions. The differences in mend the hold across the various jurisdictions recognizing the doctrine further complicate the issue. ${ }^{14}$

"304 US 64, 78 (1938).

${ }^{12}$ See S.A. Healy Co v Milwaukee Metropolitan Sewerage District, 60 F3d 305, 312 (7th Cir 1995) ('Under Erie, this 'favoritism' is to operate even when the persons who have a dispute over state law find themselves in a federal court."); Barron v Ford Motor Company of Canada, Ltd, 965 F2d 195, 199 (7th Cir 1992) (explaining that "a substantive rule is concerned with the channeling of behavior outside the courtroom").

${ }^{13}$ See Burlington Northern Railroad Co $v$ Woods, 480 US 1, 4-5 (1987). See also S.A. Healy Co, 60 F3d at 310 (describing cases in which a Federal Rule conflicts with a state rule as "pretty clear"); Charles Alan Wright, Arthur R. Miller, and Edward H. Cooper, 19 Federal Practice and Procedure: Jurisdiction $2 d \S 4511$ at 311-12 (West 2d ed 1996) (explaining that there is no longer any significant Erie problem with regard to matters covered by a Federal Rule).

1 The Seventh Circuit has "left open the question whether the [Illinois] mend the hold' doctrine . . . is substantive or procedural for purposes of the Erie doctrine." AM International, Inc $v$ Graphic Management Associates, Inc, 44 F3d 572, 576 (7th Cir 1995). However, a more recent opinion suggests that the Seventh Circuit will ultimately characterize mend the hold as a substantive rule. See Horwitz-Matthews, Inc $v$ City of Chicago, 78 F3d 1248, 1251-52 (7th Cir 1996) (explaining that, even though the pleadings were not yet complete, "the 'mend the hold' doctrine" would not permit the defendant to change its position later on because it had "emphatically assert[ed] its position" on appeal). Lower federal courts applying Illinois law have come down on both sides. Compare In re Apex Automotive Warehouse LP, 205 Bankr 547, 553-54 (Bankr N D Ill 1997) (avoiding a conflict between Illinois mend the hold and the Federal Rules by refusing to apply the doctrine "at the pleading stage of a litigation"), with Cleveland Hair Clinic, Inc v Puig, $949 \mathrm{~F}$ Supp 595, $600 \mathrm{n} 10$ (N D Ill 1996) (assuming that the doctrine is substantive), and Mellon Bank, N.A. v Miglin, 1994 US Dist LEXIS 15439, *16 (N D Ill) (Adopted Magistrate's Opinion), affd, 1995 US Dist LEXIS 2202, *6 (N D Ill) (applying Illinois mend the hold despite possible conflict with FRCP 15). The Sixth Circuit, in contrast, recently enforced the Tennessee version of the doctrine without noting a potential Erie problem. Life Care Centers of America, Inc $v$ Charles Town Associates Ltd, 79 F3d 496, 508-09 (6th Cir 1995). See note 139. The Second Circuit and various lower federal courts have applied versions of the doctrine in diversity cases without pausing to consider whether it is a substantive rule or not. See, for example, Corporacion De Mercadeo Agricola v Mellon Bank International, 608 F2d 43, 48 (2d Cir 1979) (explaining that under New York law, "when a bank offers one reason for refusing a draft on a letter of credit, and that reason is later refuted, it cannot at trial point to an entirely different reason for sustaining the refusal"); Village of Morrisville Water \& Light Department $v$ United States Fidelity \& Guaranty Co, 775 F Supp 718, $724 \mathrm{n} 7$ (D Vt 1991) (treating the Vermont version as though it were substantive); Emmons $v$ Ingebretson, 279 F Supp 558, 573 (N D Iowa 1968) (treating the Iowa version as though it were substantive). 
This Comment explores the mend the hold doctrine and its "vexing"15 Erie analysis. Part I sketches the doctrinal distinctions between mend the hold, equitable estoppel, and judicial estoppel, and then presents an outline of mend the hold as a rule of contract law. With that background in place, Part I explores some of the more significant modern manifestations of the mend the hold principle in the law of contracts. Part II considers whether federal courts sitting in diversity should enforce the mend the hold doctrine. First, it contrasts mend the hold with the flexible pleading requirements of the Federal Rules of Civil Procedure. Second, it examines the operation of the doctrine in light of Erie's "twin aims" of avoiding forum shopping and inequitable administration of the law. ${ }^{16}$ The first half of Part II argues that no Federal Rule directly conflicts with the doctrine, and thus the Rules pose no bar to its application in federal diversity actions. The second half argues that, under Erie, mend the hold is a substantive rule of law. This Comment concludes, therefore, that mend the hold is the sort of state prerogative that federal courts sitting in diversity must respect.

\section{THE "MEND THE HOLD" DOCTRINE}

Before exploring the mend the hold doctrine in detail, it is helpful to compare judicial and equitable estoppel to mend the hold. Because all three doctrines have common historical roots and share the characteristic of denying a party the right to shift its position from one asserted earlier, they are sometimes confused. ${ }^{17}$ Nevertheless, their present doctrinal definitions are quite distinct.

\section{A. Mend the Hold, Equitable Estoppel, and Judicial Estoppel}

The mend the hold doctrine, in its majority (and most severe) form, limits a party's defenses for breaking a contract to those based on a prelitigation explanation for nonperformance given to the other party. ${ }^{18}$ The most common justification for the doctrine

${ }^{15}$ Northrop Corp v Litronic Industries, 29 F3d 1173, 1177 (7th Cir 1994).

${ }^{16}$ Hanna v Plumer, 380 US 460, 468 (1965).

${ }^{17}$ The similarity between the mend the hold doctrine and judicial estoppel has not gone unnoticed by the courts. See Harbor Insurance, 922 F2d at 364 (distinguishing mend the hold from judicial estoppel).

${ }^{18}$ See, for example, Heidner, 199 P2d at 484 ("Since the defendant here, before litigation was commenced, gave only as its reason for nonperformance a ground which was inadequate, it could not, after suit was filed, 'mend its hold' and rely upon other and different defenses. It was limited in the trial to the single defense it asserted at the time of breach."). 
is that it allows a contracting party to rely on the given explanation as exclusive. Thus, if the party willing to perform wishes to save the deal, it may try to obviate the other party's reason for not performing with the assurance that other impediments to performance are not lurking in the background. ${ }^{19}$ The mend the hold doctrine, by definition, applies only to contract disputes. ${ }^{20}$

The doctrine of equitable estoppel differs from mend the hold in that it binds a party to a prior position during subsequent litigation only if the other party has relied to its detriment on that prior position. ${ }^{21}$ This requirement of detrimental reliance reflects equitable estoppel's underlying policy of protecting litigants from "less than scrupulous opponents." In contrast, mend the hold has the narrower focus of ensuring an opportunity to cure.

The third doctrine, judicial estoppel, bars a party from asserting a position inconsistent with one that it prevailed with in a prior litigation. ${ }^{23}$ Unlike mend the hold and equitable estoppel, which focus on the effect of shifting positions on the other party, judicial estoppel aims to protect the integrity of the judicial system. The doctrine prevents perjury and ensures that no two courts rule in a party's favor on conflicting theories, for then one would have to be wrong. ${ }^{24}$ As with equitable estoppel, judicial estoppel is applicable in any type of case, not just contract disputes.

19 See, for example, Nashville Marketplace Co v First Capital Institutional Real Estate, Ltd, 1990 Tenn App LEXIS 212, *16 ("Nashville Marketplace could have attempted to cure these problems before the expiration of the earn-out period had they been mentioned in the rejection notice."); Duclos v Cunningham, $102 \mathrm{NY} 678,679,6 \mathrm{NE} 790,790$ (1886) (No such objection was taken at the time by the defendants, and, had it been, the diffculty, no doubt, would have been obviated at once by the [broker].").

${ }^{20}$ See, for example, Friel $v$ Jones, 42 Del Chanc 148, 153-54, 206 A2d 232, 235 (1964) (recognizing the mend the hold principle, but finding it inapplicable on the facts of the case presented because the claim did not arise from contractual rights).

${ }^{21}$ See, for example, Schroeder v Texas Iron Works, Inc, 813 SW2d 483, 489 (Tex 1991) (explaining that equitable estoppel requires a showing of "(1) a false representation or concealment of material facts, (2) made with knowledge, actual or constructive, of those facts, (3) with the intention that it should be acted on, (4) to a party without knowledge, or the means of knowledge of those facts, (5) who detrimentally relied upon the misrepresentation").

${ }^{22}$ Edwards v Aetna Life Insurance Co, 690 F2d 595, 598 (6th Cir 1982).

${ }^{23}$ Id; Chaveriat $v$ Williams Pipe Line Co, 11 F3d 1420, 1427-28 (7th Cir 1993).

${ }^{2}$ See Rissetto $v$ Plumbers and Steamfitters Local, 94 F3d 597, 600-01 (9th Cir 1996) (explaining that judicial estoppel "precludes a party from gaining an advantage by taking one position, and then seeking a second advantage by taking an incompatible one"); Chaveriat, 11 F3d at 1427-28 (explaining that courts enforce judicial estoppel "to prevent situations from arising in which one of two related decisions has to be wrong because a party took opposite positions and won both times"); Edwards, 690 F2d at 598 (explaining that judicial estoppel protects the integrity of the judicial process by avoiding inconsistent judicial decisions). 
With the distinctions between these three doctrines established, an examination of mend the hold's evolution as a rule of contract law will further illustrate how it differs from judicial and equitable estoppel. This history will also shed light on why modern courts continue to confuse the three.

B. Evolution of Mend the Hold as an Independent Contract Rule

In its majority version, the mend the hold doctrine limits a nonperforming party's potential defenses for breaking a contract to those based on the prelitigation explanation for nonperformance that was given to the other party. ${ }^{25}$ In its minority form, mend the hold permits the changing of a contracting party's litigation posture only when that change comports with the implied duty of good faith that modern courts read into every contract. ${ }^{26}$ Both versions of the doctrine trace their roots to the Supreme Court's 1877 opinion in Railway Co $v$ McCarthy, ${ }^{27}$ the first reported decision to use the phrase.

In McCarthy, the defendant railroad refused to perform on a delivery contract, explaining that it lacked enough cars to make the delivery. ${ }^{28}$ After the litigation began, the railroad, having fortuitously refused to perform on a Sunday, tried to defend its nonperformance under West Virginia's Sunday Law, which forbade Sunday (Sabbath) deliveries. ${ }^{29}$ The Supreme Court affirmed the trial judge's refusal to instruct the jury on the Sunday law defense, calling it "an after-thought[ ] suggested by the pressure and exigencies of the case. ${ }^{.30}$ It further explained:

Where a party gives a reason for his conduct and decision touching any thing involved in a controversy, he cannot, after litigation has begun, change his ground, and put his conduct upon another and a different consideration. He is not permitted thus to mend his hold. He is estopped from doing it by a settled principle of law. ${ }^{31}$

This passage may boast among its legacy the mend the hold doctrine $^{32}$ as well as numerous judicial and equitable estoppel deci-

${ }^{25}$ See note 58 and accompanying text.

${ }^{26}$ See notes 103-08 and accompanying text.

${ }^{27} 96$ US 258, 267-68 (1877).

${ }^{23}$ Id at 265 .

2 Id at 265-67.

${ }^{30}$ Id at 267.

${ }^{31}$ Id at 267-68 (emphasis added).

See, for example, Gibson v Brown, 214 Ill 330, 341, 73 NE 578, 582 (1905), quoting McCarthy, 96 US at 267-68. See also note 48 . 
sions..$^{33}$ Indeed, some courts focused on the mention of "estoppe[1]" in the passage and therefore refused to enforce mend the hold independently of equitable estoppel. ${ }^{34}$ The Supreme Court also quoted the McCarthy mend the hold passage in its first judicial estoppel case, ${ }^{35}$ causing confusion that lingers even today. ${ }^{36}$

Although they lack the catchy wrestling phrase, a number of pre-McCarthy opinions employ mend the hold reasoning, of which the McCarthy Court cited six. Three of these cases, Everett $v$ Saltus, ${ }^{37}$ Holbrook $v$ Wight, ${ }^{38}$ and Winter $v$ Coit, ${ }^{39}$ were actions of replevin or trover stemming from contractual relationships. ${ }^{40}$ In each, the court rejected the defendant's claim of a lien on the contested property, reasoning that the defendant had failed to assert that defense at the time the plaintiff (or the plaintiff's agent) demanded return of the property. ${ }^{41}$ Put another way, these courts

${ }^{33}$ See Seminole Securities $v$ Southern Life Insurance Co, 182 F 85, 97 (Cir Ct E D NC 1910), quoting $M c$ Carthy to support its refusal to allow three defendants to take inconsistent positions in different suits; Winmark Limited Partnership v Miles \& Stockbridge, 345 Md 614, 620, 693 A2d 824, 827 (1997), quoting McCarthy's mend the hold language in support of the "doctrine of judicial estoppel"; Salcedo v Asociacion Cubana, Inc, 368 S2d 1337, 1339 (Fla Dist Ct App 1979) ("In earlier times, the rule we apply in this case [estoppel] was said to reflect the feeling that a party may not 'mend his hold' . ..."), citing McCarthy, 96 US at 268. Compare American Sulphur Royalty Co v Freeport Sulphur Co, $276 \mathrm{SW} 448,459$ (Tex App 1925) (rejecting mend the hold in favor of equitable estoppel).

${ }^{34}$ See, for example, Second National Bank of Allegheny $v$ Lash Corp, 299 F 371, 372 (3d Cir 1924) ("The concluding words clearly indicate that the rule is founded on equitable estoppel."); American Sulphur, $276 \mathrm{SW}$ at 459 (rejecting McCarthy's mend the hold rule in favor of equitable estoppel and its reliance requirement); Amsinck \& Co v Springfield Grocer Co, 7 F2d 855, 859-60 (8th Cir 1925) (explaining that "the doctrine" announced by McCarthy "is based on equitable estoppel"). Compare Larson v Johnson, 1 Ill App 2d 36, 46,116 NE2d 187, 191 (1953) ("We have concluded from our examination of the cases that so far as the Illinois doctrine is concerned, it is not limited to equitable estoppel. The reviewing courts which announced the principle were familiar with the doctrine of equitable estoppel and there was no occasion for dressing it up with a subtitle.").

${ }^{36}$ Davis $v$ Wakelee, 156 US 680, 690-91 (1895), quoting McCarthy, 96 US at 267-68.

${ }^{*}$ See, for example, Patz $v$ St Paul Fire \& Marine Insurance Co, 15 F3d 699, 703 (7th Cir 1994) ("By their mention of judicial estoppel the [plaintiffs] may have been groping for a related but separate doctrine, that of 'mend the hold' ...."); Rottmund $v$ Continental Assurance Co, 813 F Supp 1104, 1111 (E D Pa 1992), citing Harbor Insurance, 922 F2d at $362-65$, to support its use of the "common law 'mend the hold' doctrine" to bar a party from taking a position in the present litigation different from "the position[ ] it took in the prior litigation" unless "new information" justified the change.

${ }^{37} 15$ Wend 474, 474 (S Ct NY 1836).

${ }^{36} 24$ Wend 168, 169 (S Ct NY 1840).

307 NY 288, 288 (1852).

to At common law, replevin and trover were writs by which one obtained a judgment ordering the return of, or awarding damages in the value of, his or her property wrongfully in the possession of another. See Grant S. Nelson, William B. Stoebuck, and Dale A. Whitman, Contemporary Property 30-31 (West 1996).

${ }^{4}$ Everett, 15 Wend at 478 ("But if the defendants had a lien, they waived it by not putting themselves upon that ground when the property was demanded by the plaintiff's agent.") (emphasis omitted); Holbrook, 24 Wend at 179 ("But if this were not so, and sup- 
held that the defendants' prelitigation explanations barred them from mending their hold at trial.

The other three cases cited by the McCarthy Court involved waivers of arguments by failure to assert them when rejecting a tender. In Wright $v$ Reed, ${ }^{42}$ a 1790 English case, one judge opined that because no objection was made at the time, "bank notes" drawn on the Bank of England constituted a valid performance even though the contract called for consideration in "money." In Gould $v$ Banks \& Gould, ${ }^{44}$ a New York trial court found that the plaintiff had stated at the time that he would not accept a shipment of books because they were in poor condition, not because they were late. Therefore, it held that "[u]pon well settled principles, this was a waiver of all other objections to the tender. ${ }^{\$ 45}$ Finally, only seven years before McCarthy, the New York Court of Appeals in Duffy $v$ O'Donovan ${ }^{46}$ explained:

It is urged that the tender was insufficient, as it was not in money. But it was not refused for that reason. It was rejected because not made in time, and not because the certified check was not money or legal tender. It cannot now be objected, that the party could not have been compelled to accept a certified check in lieu of money. He waived his right to demand the money by not asserting it at the proper time. ... The objection to the tender could have been obviated, and, therefore, was waived, not having been taken. ${ }^{47}$

Building upon this foundation, courts in the early 1900s further developed the doctrine. ${ }^{48}$ Some limited its application to

posing the question of lien to rest on what the defendant's partner said when the demand was made, omitting to mention a lien and taking other ground, waives it."); Winter, 7 NY at 293-94 ('The jury were properly instructed as to the waiver of the defendants' lien for their charges for insurance, freight, cartage, labor, storage and fire insurance, that if on being apprised of the plaintiffs claim, they put themselves not upon their lien but only upon the denial of plaintiff's right, they could now assume a different ground."), citing Holbrook, 24 Wend at 169.

3 D \& E 554, 100 Eng Rep 729 (KB 1790).

4300 Eng Rep at 729 (opinion by Buller).

« 8 Wend 562, 567 (S Ct NY 1832).

${ }^{4} \mathrm{Id}$.

46 NY 223 (1871) (citations omitted).

${ }^{47}$ Id at 227-28 (citations omitted). Note the striking resemblance to the dispute over whether "bank notes of the bank of England" constituted a tender of "money" in Wright, 100 Eng Rep at 729.

${ }^{48}$ See, for example, Oakland Sugar Mill Co $v$ Fred W. Wolf Co, 118 F 239, 248-50 (6th Cir 1902) (deciding not to "permit the purchaser . . . to change the issues and propound new defenses"), citing McCarthy, the six cases cited in McCarthy, and a number of other cases; E.E. Taenzer \& Co v Chicago, Rhode Island \& Pacific Railway Co, 191 F 543, 551 (6th Cir 1911) (excepting from mend the hold defenses based on "contravention of the public policy of the United States as expressed by its positive statutes," and describing the 
cases in which the party asserting the doctrine could have cured the reason for the other party's nonperformance. ${ }^{49}$ (The language in Duffy excerpted above suggests this limitation.) Other courts, in what would lead to the modern majority rule, applied an absolute form of the doctrine. That is, these courts limited a breaching party's defenses to a prelitigation explanation for nonperformance regardless of that party's good faith reasons for changing positions and the other party's ability to cure. ${ }^{50}$ Foreshadowing what would become the modern minority rule, the Supreme Court of Michigan connected the rule to the obligation of contracting parties to act in good faith. ${ }^{51}$

Finally, departing from the context of contracts and estoppel, some post-McCarthy courts employed the phrase "mend the hold" to refer to the familiar rule of appellate procedure that arguments not raised at trial are waived on appeal; ${ }^{52}$ to sundry other

Sunday law part of McCarthy as "more or less obiter"); Continental National Bank $v$ National City Bank of New York, 69 F2d 312, 318-19 (9th Cir 1934) (collecting cases and describing the conflict among the courts in interpreting the McCarthy rule). See also Larson, 116 NE2d at 192 ("This is how the doctrine emerges from the cases which have considered it. ... [T]

49 See, for example, Continental National Bank, 69 F2d at 319 ("In the relevant cases in this circuit, the requirement that the plaintiff should have been misled to his damage has not been expressly stated, but it appeared from the facts that there was some possibility that he might have cured the defects had they been called to his attention, although perhaps not within the time limits of the contract."); Western Grocer Co $v$ New York Oversea Co, 28 F2d 518, 520-21 (N D Cal 1928) ("A party to a contract is not permitted to refuse to perform a contract upon one ground, and later to rely upon another ground, which might have been remedied, had it been called to the attention of the performing party.").

${ }^{s}$ See, for example, Luckenbach S.S. Co, Inc $v$ W.R. Grace \& Co, 267 F 676, 679 (4th Cir 1920) ("But the further and equally conclusive answer is found in the settled rule of law that one who breaches his contract for reasons specified at the time will not be permitted afterwards, when sued for damages, to set up other and different defenses. This rule has been long established and frequently applied."); Wyatt $v$ Henderson, 31 Or 48, 54, 48 P 790,792 (1897) ("The defendants, having denied, upon information and belief, that the plaintiff was the owner or entitled to the possession of any of the said oats, cannot now be permitted to say that their refusal to deliver the grain in question was caused by the failure of the plaintiff to pay the storage thereon.").

${ }^{81}$ Smith, County Treasurer v German Insurance Co, 107 Mich 270, 279, 65 NW 236, 239 (1895) ("It is apparent that the ground, and the only ground, upon which all liability was denied, was the storage of gasoline .... Good faith required that the [insurance] company should apprise the plaintiff fully of its position; and, failing to do this, it estops itself from asserting any defense other than that brought to the notice of plaintiff.").

${ }^{82}$ See, for example, Vileski v Pacific-Atlantic Steamship Co, 163 F2d 553, 555-56 (9th Cir 1947) (explaining that the "[1]ibelant on this appeal seeks to raise a new issue," but holding that the "libelant is not entitled so to mend his hold"); Arkansas Anthracite Coal \& Land Co $v$ Stokes, 2 F2d 511, 515 (8th Cir 1924) ("But it is also well-nigh universal and fundamental, as a rule of appellate procedure, that a litigant may not mend his hold on the way up to an appellate court by seeking to reverse a case, because the theory on which it was tried below, and in which appellants then acquiesced, is, in fact, erroneous. In short, to state the rule simply and baldly, the theory on which a case is tried nisi is the theory in which it must, on appeal, be weighed for error."); Bob v Hardy, 222 Ga App 550, 
rules barring amendment of one's position; ${ }^{63}$ and to describe the shifting of one's grounds. ${ }^{54}$ None of these uses is particularly relevant to the present inquiry into the contract law mend the hold principle, other than perhaps to illustrate that several judges have (or had) a tendency to use the phrase repeatedly, suggesting that, although possibly quirky ${ }^{55}$ or quaint, ${ }^{56}$ this relatively esoteric phrase endears itself to those who encounter it. ${ }^{57}$

\section{The Majority Rule: Prelitigation}

Presently, the dominant form of the mend the hold doctrine limits a contracting party's defenses for nonperformance to those based on explanations given at the time of the nonperformance. Hence the doctrine binds contracting parties, during litigation, to

554,474 SE2d 658, 662 (1996) ("One cannot expand the scope of review or supply additional issues through a process of switching, shifting, and mending your hold.") (internal citations and quotation marks omitted); Beard $v$ Montgomery Ward and Co, 215 Kan 343, 349, 524 P2d 1159, 1165 (1974) ("If a case has been tried upon one theory, it is too late to mend his hold and advance another theory which might have been, but was not, presented at the trial.") (internal citations and quotation marks omitted); H.W. Ivey Construction Co $v$ Transamerica Insurance Co, 119 Ga App 794, 795, 168 SE2d 855, 856 (1969) (explaining that on appeal the plaintiff "must stand or fall upon the position taken in the trial court," and thus he "cannot ... mend his hold"); Harlan Production Credit Association v Schroeder Elevator Co, 253 Iowa 345, 349, 112 NW2d 320, 323 (1961) (rejecting an argument on appeal because the "record indicates the contention was not made in the trial court and is an attempt by plaintiff to mend its hold here"). Compare Domino Sugar Corp v Sugar Workers Local Union 392, 10 F3d 1064, 1068 (4th Cir 1993) ("Ordinarily an appellate court does not give consideration to issues not raised below.").

${ }^{\$ 3}$ See, for example, Claeys v Moldenschardt, 260 Iowa 36, 41, 148 NW2d 479, 482 (1967) ("Rather she attempted to mend her hold under rule 252 by asserting a new and independent action upon a basis foreign to that rule under the guise of an amendment. This she could not do."); Norton v Crescent City Ice Manufacturing Co, Inc, $178 \mathrm{La} \mathrm{135}$, $145,150 \mathrm{~S} 855,858$ (1933) ("They did not choose to [amend their pleadings], and we do not think that at this late date they should be permitted to mend their hold and to subject defendant to the annoyance and expense of further litigation .....").

st See, for example, Babbitt $v$ Sweet Home Chapter of Communities for a Great Oregon, 515 US 687, 734 (1995) (Scalia dissenting) ("The second point the Court stresses in its response seems to me a belated mending of its hold."); In re Berkowitz, 3 Kan App 726, 747, 602 P2d 99, 114 (1979) (noting that a second criminal trial "permits the prosecution to 'mend its hold' in the light of experience in the first trial"); Seaboard Sand \& Gravel Corp $v$ American Stevedores, Inc, 151 F2d 846, 847 (2d Cir 1945) ("As the scales tipped one way or the other, or remained even, as the trial proceeded, either party could, of course, mend its hold as its evidence enabled it to do; but if in the end the proof did not preponderate at least to a slight extent to show negligence the libelant failed to prove a case.").

${ }^{\text {ss }}$ Harbor Insurance, 922 F2d at 363 ("Harbor and Allstate describe the 'mend the hold' doctrine as 'quirky.' The name is quirky, but....”).

${ }^{s 8}$ Edwards Manufacturing Co $v$ Bradford Co, 294 F 176, 181 (2d Cir 1923) ("But afterthoughts in litigations do not permit a party 'to mend his hold,' as was quaintly but effectively said in Railway Co. v. McCarthy.") (citations omitted).

${ }^{67}$ Learned Hand, for example, used the phrase in three different opinions, each time descriptively. See Schwartz v Horowitz, 131 F2d 506, 508 (2d Cir 1942); Cohan v Richmond, 86 F2d 680, 682 (2d Cir 1936); Connolly $v$ Medalie, 58 F2d 629, 630 (2d Cir 1932). 
prelitigation statements. Over the last fifty years, courts applying the laws of Delaware, the District of Columbia, Georgia, Iowa, Kansas, Michigan, Nebraska, New Jersey, New York, Oregon, Tennessee, Texas, and Vermont have enforced this version of the doctrine either by name or in practice at least once. ${ }^{58}$

${ }^{s 8}$ See, for example, Friel $v$ Jones, 42 Del Chanc 148, 153-54, 206 A2d 232, 235 (1964) (recognizing the mend the hold doctrine, but finding it inapplicable because suit did not arise from contractual rights); Keefe v Moskin Stores, 95 A2d 336, 339 (DC App 1953) (barring a store manager who had refused to recognize his termination "from denying his obligation under the employment contract”); Weldon v Lashley, $214 \mathrm{Ga} 99,102-04,103 \mathrm{SE2d}$ $385,388-89$ (1958) (recognizing the mend the hold doctrine, but finding it inapplicable because the defendant had made no prior inconsistent justification for the alleged breach). But compare Adler's Package Shop, Inc v Parker, 190 Ga App 68, 73, 378 SE2d 323, 327 (1989) (recasting Weldon's mend the hold rule as one of estoppel, and thus requiring detrimental reliance); Blunt $v$ Wentland, 250 Iowa 607, 615, 93 NW2d 735, 739 (1959) ("Having elected to repudiate, the appellant was not entitled afterwards to mend his hold by insisting that, if he had not repudiated the contract, the purchaser would not instantly have been able to produce the required cash payment. That a party who has elected one ground of objection cannot afterwards mend his hold and select another, which might have been obviated, had it been insisted upon, is well settled."), quoting Crow $v$ Casady, 191 Iowa 1357, 182 NW 884 (1921); Russell v Ferrell, 181 Kan 259, 269, 311 P2d 347, 354 (1957) (explaining that, because "[t]ender of payment was refused on the sole ground that the Russells were too late," the refusing party "may not "mend his hold" by raising another ground); Tackels, Inc $v$ Fantin, 341 Mich 119, 124, 67 NW2d 71, 73-74 (1954) ("At. that time defendant's expressed reluctance to proceed with the work resulted from his belief that the bid price was too low to cover the cost of labor and materials. He did not indicate by his statements that refusal to do the work contemplated was, or would be, predicated on the theory that acceptance of the offer was precluded because of delay on the plaintiffs part. The failure to assign such reason is significant."), citing McCarthy, 96 US at 267-68; Design Data Corp v Maryland Casualty Co, 243 Neb 945, 956-57, 503 NW2d 552, 559-60 (1993) (refusing to apply the otherwise alive "rule as to mending one's hold" in disputes involving insurance coverage); Schanerman v Everett \& Carbin, Inc, $10 \mathrm{NJ}$ $215,220-21,89$ A2d 689, 692 (1952) (disallowing an argument based on the buyer's financial ability because the "prospective seller in refusing to execute the contract asserted simply that it was withdrawing the property from the market and did not question the buyer's financial ability"); Corporacion De Mercadeo Agricola v Mellon Bank International, 608 F2d 43, 48-49 (2d Cir 1979) (explaining that, under New York law, "when a bank offers one reason for refusing a draft on a letter of credit, and that reason is later refuted, it cannot at trial point to an entirely different reason for sustaining the refusal"); Wyoming Sawmills, Inc v Transportation Insurance Co, 282 Or 401, 408-10, 578 P2d 1253, 1257-58 (1978) (In Banc) (limiting the rule, "which is securely rooted in common justice," in insurance cases so as not to create "an original grant of coverage where no such contract previously existed") (internal citations and quotation marks omitted); Nashville Marketplace Co, 1990 Tenn App LEXIS 212 at *16 ("Admittedly, the contract documents did not specifically require the First Capital defendants to set out the grounds for their rejection of a lease. However, once a contracting party has given reasons for its actions, it cannot attempt to justify its conduct on new and different grounds after suit is filed."); Measday $v$ Kwik-Kopy Corp, 713 F2d 118, 125-26 (5th Cir 1983) ("In Texas when an employer assigns grounds for discharge of an employee, it cannot later justify the termination on grounds that were not made the basis of the termination at the time of the discharge."); Hamlin $v$ Mutual Life Insurance Co, 145 Vt 264, 267-70 \& n 2, 487 A2d 159, 161-63 \& n 2 (1984) (discussing the "insurance defense waiver rule"). 
The majority rule is one of general application, meaning that it does not discriminate between types of contracts. ${ }^{59}$ Nevertheless, the rule has been discussed as especially applicable to insurance coverage ${ }^{60}$ and real estate brokerage contract disputes, ${ }^{61}$ and in both of these contexts, some courts have limited the rule's otherwise wide reach. ${ }^{62}$ Similarly, UCC § 2-605 modifies the rule in disputes over contracts for the sale of goods. ${ }^{63}$

\section{Mend the hold in the insurance context.}

The comparatively more frequent use of the mend the hold doctrine in insurance cases may stem from insurance companies' practice of writing letters to policyholders to explain their reasons for denying a claim. Certainly at a minimum these letters, typically referred to as "declination letters," ameliorate the problems of proof associated with a verbal refusal to perform. Whatever the reason for its more frequent invocation in insurance disputes, this relative frequency has engendered a number of interesting doctrinal developments.

For example, the Vermont Supreme Court has recast the doctrine as the "insurance defense waiver rule."64 Vermont courts justify this version of the doctrine with a "public policy" of honesty. ${ }^{65}$ The motivating notion is to hold an insurer to his word once he "puts his refusal to pay on a specified ground." courts operate on the assumption that the insured has relied on the declination letter in bringing the suit, ${ }^{67}$ thus moving the doctrine closer to equitable estoppel. Yet despite these nuances, the

${ }^{50}$ See, for example, Nashville Marketplace Co, 1990 Tenn App LEXIS 212 at *16 ("LO]nce a contracting party has given reasons for its actions, it cannot attempt to justify its conduct on new and different grounds after suit is filed.").

${ }^{\infty}$ See, for example, Hamlin, 487 A2d at 161-63 \& $\mathrm{n} 2$ (discussing the "insurance defense waiver rule").

${ }^{61}$ See 12 Am Jur 2d Brokers § 251 (1997) ("As a general rule, where a landowner who has listed property for sale with a real estate broker refuses to accept an offer which is substantially in accordance with the listing, the owner cannot afterwards defend the broker's action for compensation on a ground not specified when rejecting the offer.").

${ }^{62}$ For examples of courts that have limited mend the hold's application in the insurance and real estate contexts, see Parts I.C.1 and I.C.2.

${ }^{*}$ See text accompanying note 89. Compare Polson Logging Co v Neumeyer, 229 F 705, 707 (9th $\mathrm{Cir}$ 1916) (affirming a judgment for the seller because "the purchaser refused to receive the steel ... solely upon" two specific grounds different from the "objections now relied upon to defeat the action").

*t Hamlin v Mutual Life Insurance Co, 145 Vt 264, 267-70, 487 A2d 159, 161-63 (1984).

${ }^{65}$ Cummings v Connecticut General Life Insurance Co, 102 Vt 351, 148 A 484, 487 (1930).

${ }^{6}$ Id.

${ }^{67}$ Id (discussing the unfairness of allowing the insurance company to mend its hold "after the insured has taken him at his word and is attempting to enforce his liability"). 
insurance defense waiver rule appears to have little practical utility. Its effect is to give incentive to insurance companies simply to reserve all of their rights in a declination letter, rather than limiting themselves to a specific reason for refusing to pay. ${ }^{68}$

In contrast to Vermont, where the insurance defense waiver rule remains alive and well, ${ }^{69}$ both Nebraska and Oregon have consistently eschewed enforcing a robust form of the doctrine in insurance coverage cases. ${ }^{70}$ Both of these states have recently carved out an exception to mend the hold for policy exclusions and other defenses that go to the original scope of the coverage. That is, regardless of the reasons asserted in a prelitigation declination letter, in Nebraska (with an exception discussed below) and Oregon, an insurance company may always defend its refusal to pay by arguing that the insured's loss does not fall within the policy's ambit. ${ }^{11}$

The Oregon exception incorporates into mend the hold the common rule of insurance law that policyholders cannot invoke estoppel to extend the scope of coverage. ${ }^{72}$ The relevant inquiry

See, for example, In re Aberdeen 100, Inc, 1995 Bankr LEXIS 1032, *11 (Bankr D Vt) (holding that the defendant insurance company "waived nothing" because it had "specifically 'reserve[d] its rights to disclaim coverage" under any other grounds). Compare note 81 and accompanying text.

- See id at *9-11 (recognizing the rule as the law of Vermont); Village of Morrisville Water \& Light Department $v$ United States Fidelity \& Guaranty Co, 775 F Supp 718, 724 n 7 (D Vt 1991) (same).

${ }^{70}$ For Nebraska examples, see O'Neil $v$ Union National Life Insurance Co, $162 \mathrm{Neb}$ 284, 291, 75 NW2d 739, 744 (1956) (refusing to bar an amendment because the "amended answer as to this subject did not" represent a change in "its defensive position"); Pickens $v$ Maryland Casualty Co, 141 Neb 105, 110, 2 NW2d 593, 596 (1942) (allowing the insurance company to mend its hold because the declination letter "inadvertently" misstated the company's rationale and the "error was so patent that it can in no way prejudice the rights of defendant"). For Oregon examples, see Ward $v$ Queen City Fire Insurance Co of Sioux Falls, 69 Or 347, 352, 138 P 1067, 1068 (1914) (suggesting that mend the hold applies only to the extent that the party in breach was in full possession of "all the facts and circumstances"); Eaid v National Casualty Co, 122 Or 547, 557-59, 259 P 902, 906 (1927) (following Ward, and thus applying mend the hold because "the company had made a careful examination and investigation of the [plaintiff's] claim").

${ }^{71}$ Design Data Corp $v$ Maryland Casualty Co, 243 Neb 945, 957, 503 NW2d 552, 560 (1993) ('While the rule as to 'mending one's hold' may be alive and well as to conditions of forfeiture, generally it has no application to matters relating to coverage, and estoppel cannot be invoked to expand the scope of coverage of an insurance contract absent a showing of detrimental good faith reliance upon statements or conduct of the party against whom estoppel is invoked which reasonably led an insured to believe coverage was present."); $A B C D$... Vision, Inc $v$ Fireman's Fund Insurance Co, 304 Or 301, 306, 744 P2d 998, 1001 (1987) ("Estoppel cannot be invoked to expand insurance coverage or the scope of an insurance contract."); Wyoming Sawmills, Inc v Transportation Insurance Co, 282 Or 401, 578 P2d 1253, 1258 (1978) (In Banc) (limiting the mend the hold rule so as not to create a "grant of coverage where no such contract previously existed").

72 Wyoming Sawmills, 578 P2d at 1257-58. See also DeJonge v Mutual of Enumclaw, 315 Or 237, 843 P2d 914, 916-17 (1993) (In Banc), citing Wyoming Sawmills, 578 P2d at 
thus becomes how to distinguish matters of forfeiture from questions about the scope of coverage. A forfeiture of coverage occurs when "there is insurance coverage for the loss in the first place, but acts of the insured nullify the coverage, such as the filing of a false statement . . . ."73 In other words, an insurance company in Oregon may always raise a policy exclusion defense ${ }^{74}$ or argue that a claim does not fall "within the insuring clause originally granting coverage. ${ }^{m 5}$ Insureds, however, may still defeat defenses based on a forfeiture argument (as opposed to a coverage argument) if the insurance company fails to raise that defense in its declination letter. ${ }^{76}$

Two observations about this modification are worth noting. First, it provides another example of the influence of estoppel on the development of mend the hold; the change represents nothing more than the grafting of a limitation on estoppel onto the mend the hold doctrine. Second, so long as insurance companies consistently reserve all of their rights in their Oregon declination letters, the modification will have no practical effect.

The Nebraska version of this exception tracks the Oregon version-indeed, it was in part inspired by it. ${ }^{77}$ Nebraska, however, has added an additional wrinkle: plaintiffs showing "detrimental good faith reliance" may invoke "the rule as to "mending one's hold" in disputes over coverage as well as forfeiture. ${ }^{78}$ Thus,

1278 and $A B C D$... Vision, $744 \mathrm{P} 2 \mathrm{~d}$ at 1001, for the proposition that estoppel cannot be used to expand a policy's coverage. On this subject generally, see Peter Nash Swisher, Judicial Interpretations of Insurance Contract Disputes: Toward a Realistic Middle Ground Approach, 57 Ohio St L J 543, 592-94, 618-21 (1996) (discussing expansion of coverage through waiver and estoppel); W.C. Crais III, Annotation, Doctrine of Estoppel or Waiver as Available to Bring Within Coverage of Insurance Policy Risks not Covered by its Terms or Expressly Excluded Therefrom, 1 ALR3d 1139 (1965), cited with approval in DeJonge, $843 \mathrm{P2d}$ at $916 \mathrm{n} 3$. See also Employers Insurance of Wausau $v$ Ehlco Liquidating Trust, 292 Ill App 3d 1036, 687 NE2d 82, 90-93 (1997) (refusing to apply a similar Illinois insurance estoppel rule when the insurer can show the breach of a condition precedent to coverage).

${ }^{73}$ ABCD ... Vision, 744 P2d at 1002. See also George J. Couch, Ronald A. Anderson, and Mark S. Rhodes, 14 Couch on Insurance § 49B:1 (Law Co-op 2d rev ed 1982) ("Provisions in contracts of insurance requiring notice and proofs of loss, injury, death, claim against the insured, etc., may, like all other provisions or conditions which are inserted by the insurers for their benefit or protection, be waived by them .... $)$.

"ABCD... Vision, $744 \mathrm{P} 2 \mathrm{~d}$ at 1001.

${ }^{25}$ Wyoming Sawmills, 578 P2d at 1258.

${ }^{73} A B C D$... Vision, 744 P2d at 1002.

7 See Design Data, 503 NW2d at 559-60, quoting $A B C D$... Vision, 744 P2d at 100102 , with approval.

${ }^{78}$ Design Data, 503 NW2d at 560 ('While the rule as to 'mending one's hold' may be alive and well as to conditions of forfeiture, generally it has no application to matters relating to coverage, and estoppel cannot be invoked to expand the scope of coverage of an insurance contract absent a showing of detrimental good faith reliance upon statements or conduct of the party against whom estoppel is invoked which reasonably led an insured to 
in Nebraska, mend the hold operates no differently than equitable estoppel in disputes over the scope of insurance coverage.

\section{Mend the hold in the real estate context.}

Whereas the use of mend the hold in insurance contract disputes is driven by notions of honesty and the difference between forfeiture and scope of coverage, the doctrine's application to brokerage contracts is animated by a desire to ensure to the broker an opportunity to cure cited defects in a tendered buyer's offer. ${ }^{79}$ The idea is that the broker, who has a commission on the line, will work to "obtain concessions on minor problems from the prospective buyer. ${ }^{\prime 80}$ But the traditional mend the hold rule created at best mixed incentives. It encouraged sophisticated sellers to couch their refusal of a prospective buyer in general terms, thereby protecting all possible defenses for potential subsequent litigation..$^{81}$ By virtue of the generality of the refusal, the seller deprived the broker of his opportunity to cure. ${ }^{82}$

To avoid this problem, courts have limited the reach of mend the hold in brokerage contract disputes to curable defects. ${ }^{83}$ Modern courts also require the seller to provide the broker with an explanation for rejecting a tendered buyer. ${ }^{84}$ This modified mend

believe coverage was present."). See also Erickson v Carhart, 1996 Neb App LEXIS 234, *16 (explaining that Design Data 'limits the estoppel doctrine of 'mending one's hold' to prevent expansion of coverage beyond the policy terms absent detrimental reliance").

Tee, for example, Sherwood $v$ Rosenstein, 179 Minn 42, 228 NW 339, 339 (1929) ("The theory is that, if [the principal] would speak in season, the [broker] might remove the alleged obstacle ...."); Duclos, 6 NE at 790 ("No such objection was taken at the time by the defendants, and, had it been, the difficulty, no doubt, would have been obviated at once by the [broker] . . . ."). See also Lathrop $v$ Gauger, 127 Cal App 2d 754, 767, 274 P2d 730,738 (1954) ("The general rule, in this state and elsewhere, is that where a broker has produced a purchaser in substantial compliance with the terms of a listing, and the owner does not object to the terms of the proposed purchase or the details of performance but states as the reason for his refusal his unwillingness to sell, he may not shift his position, when sued for a commission, and defend upon objections to details that the broker might have supplied or corrected if they had been pointed out by the owner.").

${ }^{3}$ Horton-Cavey Realty Co v Reese, 34 Colo App 323, 328, 527 P2d 914, 917 (1974).

${ }^{81}$ Hawkland's critique of mend the hold in the context of contracts for the sale of goods is equally applicable to real estate brokerage contracts. See William D. Hawkland, Uniform Commercial Code Series § 2-605:01 (Clark Boardman Callaghan 1984) ("This rule led sophisticated buyers to object to the seller's tender in a general nonspecific fashion and to base rejection on all available grounds.").

Compare note 79.

See Mutchnick v Davis, 130 AD 417, 114 NYS 997, 999 (NY App Div 1909) (explaining that "failure to object on the ground of the party wall cannot be deemed a waiver of that defect, because it could not have been cured").

${ }^{34}$ See Record Realty, Inc $v$ Hull, 15 Wash App 826, 552 P2d 191, 195 (1976) (recognizing the majority rule requires that the seller "show that the ground for rejection of an offer tendered to the seller by the broker was specified to the broker at that time"). 
the hold rule lessens the broker's vulnerability to opportunistic behavior by the seller while ensuring the broker an opportunity to cure insubstantial defects in the tendered buyer's offer. Thus, it represents a sensible change. This configuration of the doctrine may be subsumed within the more general rule that, in the face of curable defects in a tendered buyer's offer, the seller's silence waives those defects as defenses in a subsequent suit by the broker for his commission. Courts have embraced this more general rule almost universally ${ }^{85}$ Moreover, the modified rule, by requiring disclosure of curable defects, is a more efficient route to protecting a broker from the seller's strategic behavior than either mend the hold (with its incentive structure stacked against helpful disclosures) or equitable estoppel (which does not foster disclosure of curable defects).

By tying the rule's operation to the lost opportunity to cure, and by creating an affirmative obligation on the part of the rejecting party, this configuration of the doctrine begins to resemble UCC \& $2-605$, a provision specifically designed to remedy the mixed incentives created by the common law version of mend the hold.

\section{UCC § 2-605: A codification of mend the hold?}

When the common law held exclusive dominion over disputes regarding contracts for the sale of goods, the application of mend the hold to a buyer's rejection of a seller's tender would have been straightforward: a buyer who gave an explanation for his rejection would be limited to that explanation as his only defense in a subsequent suit. ${ }^{86}$ However, as with disputes over real estate bro-

${ }^{85}$ See Horton-Cavey Realty, 527 P2d at 917; Lathrop, 274 P2d at 738; Libowitz v Lake Nursing Home, Inc, 35 Wis 2d 74, 81-82, 150 NW2d 439, 443 (1967). See also 12 Am Jur 2d Brokers $\S 251$ (1997) ("As a general rule, where a landowner who has listed property for sale with a real estate broker refuses to accept an offer which is substantially in accordance with the listing, the owner cannot afterwards defend the broker's action for compensation on a ground not specified when rejecting the offer."); Annotation, Failure, when refusing offer to purchase land, to state ground therefor as affecting right to assert such ground in defense of broker's action for compensation, 156 ALR 602 (1945). For an example of the explicit fusion of these rules, see Orange City Hills, Inc $v$ Florida Realty Bureau, Inc, 119 S2d 43, 48-49 (Fla Dist Ct App 1960) (Wigginton dissenting), which cites both an earlier edition of the relevant Am Jur section and McCarthy's mend the hold language.

${ }^{86}$ See, for example, Littlejohn v Shaw, 159 NY 188, 191, 53 NE 810, 811 (1899) ("But in this case the defendants placed their rejection of the gambier upon two specific grounds, viz. that it was not of good merchantable quality, and that it was not in good merchantable condition. By thus formally stating their objections, they must be held to have waived all other objections. The principle is plain, and needs no argument in support of it, that, if a particular objection is taken to the performance, and the party is silent as to all others, they are deemed to be waived."). See also text accompanying notes $42-47$. 
kerage contracts, the traditional mend the hold rule created an incentive not to disclose even curable defects for fear of being limited to that defense in later litigation. ${ }^{87}$ It also "penalized the buyer who gave a quick and informal notice of specific defects upon rejection." The Uniform Commercial Code ("UCC") attempted to remedy these problems.

UCC § 2-605 provides:

The buyer's failure to state in connection with rejection a particular defect which is ascertainable by reasonable inspection precludes him from relying on the unstated defect to justify rejection or to establish breach ... where the seller could have cured it if stated seasonably. ${ }^{89}$

This configuration incorporates the most salutary aspects of traditional mend the hold without its unfortunate side effect of mixed incentives. In the words of Section 2-605's official commentary:

The present section rests upon a policy of permitting the buyer to give a quick and informal notice of defects in a tender without penalizing him for omissions in his statement, while at the same time protecting a seller who is reasonably misled by the buyer's failure to state curable defects. ${ }^{90}$

Although judicial exegesis of Section 2-605 is scarce, courts have applied it without difficulty, ${ }^{91}$ and one court even noted the connection between Section 2-605 and mend the hold. ${ }^{92}$

${ }^{7}$ Hawkland, Uniform Commercial Code Series at \& 2-605:01 (cited in note 81) ("This rule led sophisticated buyers to object to the seller's tender in a general nonspecific fashion and to base rejection on all available grounds. The case law supported this approach, generally holding that if the buyer rejected without specifying any reason other than the general allegation that the goods did not conform to the contract, he had the right thereafter to rely on any defects or noncomformities to support his action.").

Id.

* UCC § 2-605(1)(a). See also UCC § 2A-514 (revising Section 2-605 to reflect leasing practices and terminology).

* UCC \& 2-605 comment 1.

${ }^{91}$ See, for example, Texpor Traders, Inc $v$ Trust Co Bank, 720 F Supp 1100, 1111-12 (S $D$ NY 1989) (applying UCC \& 2-605).

92 The court in Phillips Puerto Rico Core, Inc v Tradax Petroleum Ltd, 782 F2d 314, 321 (2d Cir 1985), after citing UCC $\S 2-605(1)$ to explain why a party "waived its right to rely on [a] belatedly alleged defect as justification for its nonpayment," string cited two earlier decisions. The first, Uchitel v F.R. Tripler \& Co, 434 NYS2d 77, 81 (NY S Ct 1980), is an unimportant Section 2-605 case. But the second, Corporacion de Mercadeo Agricola $v$ Mellon Bank International, 608 F2d 43 (2d Cir 1979), did not involve the UCC at all. Rather, in a classic application of the mend the hold principle, it explained that "when a bank offers one reason for refusing a draft on a letter of credit, and that reason is later refuted, it cannot at trial point to an entirely different reason for sustaining the refusal." Id at 48-49. See also Otto Seidenberg $v$ Tautfest, 155 Or 420, 64 P2d 534, 535 (1937) (incorpo- 
Interestingly, Section 2-605 also rests on the UCC's universal obligation of good faith. ${ }^{93}$ Viewed from that perspective, Section 2605 begins to resemble the Illinois version of mend the hold and its Massachusetts and Texas analogues.

\section{The Minority Rule: Postlitigation Good Faith}

Massachusetts and Texas have both explicitly rejected the majority, prelitigation version of mend the hold. ${ }^{94}$ In these two states, a party to a contract suit may advance any defense regardless of whether that party gave a different explanation at the time of nonperformance. However, both Massachusetts and Texas have restricted this general rule, and disallow new defenses when the nonperforming party changes positions in bad faith. ${ }^{95} \mathrm{Al}-$ though the precise definition of "bad faith" is unclear, the courts of both states distinguish bad faith from detrimental reliance, ${ }^{96}$

rating the mend the hold rule into a 1930 Oregon statute that resembles modern day UCC \$ 2-605).

${ }^{83}$ See UCC \& 2-605 comment 2 (explaining that "a buyer who merely rejects the delivery without stating his objections to it is probably acting in commercial bad faith"); UCC \& 1-203 ("Every contract or duty within [the UCC] imposes an obligation of good faith in its performance or enforcement."). See also Restatement (Second) of Contracts $\$ 248$ comment b (ALI 1979) ("[T] the other party as to induce his failure to cure the defective performance or offer of performance .... If it does so, the non-occurrence of the condition is excused . . . This is a specific application of the general rule that requires good faith and fair dealing ....").

${ }^{2}$ New England Structures, Inc $v$ Ronald $R$. Loranger, 354 Mass 62, 65-66, 234 NE2d 888, 891-92 (1968) (characterizing McCarthy and its progeny as relying on estoppel or waiver); American Sulphur, $276 \mathrm{SW}$ at 459 (rejecting McCarthy's mend the hold rule in favor of equitable estoppel and its reliance requirement). Somewhat inconsistently, Texas enforces the mend the hold principle in employment disputes, see Measday $v$ Kwik-Kopy Corp, 713 F2d 118, 125-26 (5th Cir 1983) ("In Texas when an employer assigns grounds for discharge of an employee, it cannot later justify the termination on grounds that were not made the basis of the termination at the time of the discharge."), in conflict with the Restatement. See Restatement (Second) of Contracts § 237 illustration 8 (ALI 1979) ("B is not aware of [legitimate grounds for discharging $A$, so $B$ ] discharges $A$ for an inadequate reason. A has no claim against B for discharging him.").

${ }^{9}$ Accent Builders Company, Inc v Southwest Concrete Systems, Inc, 679 SW2d 106, 110 (Tex App 1984) (holding that "absent a bad faith effort or a change of position a party is 'not prevented from relying upon one good defense among others urged simply because he has not always put it forward"), quoting New England Structures, 234 NE2d at 892; Commonwealth Mortgage Corp v First Nationwide Bank, 873 F2d 859, 866 (5th Cir 1989), quoting Accent Builders, 679 SW2d at 110. Accent Builders also cites a section of the Restatement, which relied upon the facts of New England Structures, in support of the good faith amendment rule. Accent Builders, 679 SW2d at 110, citing Restatement (Second) of Contracts \& 248. Section 248 comment b explicitly connects the proposition to "the general rule that requires good faith and fair dealing in the enforcement of contracts."

${ }^{96}$ Accent Builders, 679 SW2d at 110 ("Thus under our holding the question for the jury was not whether Accent intended to terminate for convenience, but instead whether it acted in bad faith or whether Southwest changed its position in reliance."); New England Structures, 234 NE2d at 891-92 ("While of course one cannot fail in good faith in presenting his reasons as to his conduct touching a controversy he is not prevented from relying 
suggesting that the bad faith inquiry is distinct from the reliance inquiry under equitable estoppel.

The Illinois lower courts-despite the Illinois Supreme Court's 1905 explicit adoption of the traditional McCarthy mend the hold rule $e^{97}$-have similarly recast the rule so that it no longer applies to prelitigation statements. ${ }^{98}$ This modification began in 1953 with Larson $v$ Johnson..$^{99}$ The Larson court, after rejecting an argument that mend the hold was no more than a fancy name for equitable estoppel, ${ }^{100}$ announced that it would refuse to enforce mend the hold where "the casual character of the repudiation ... would [make it] inequitable to apply the doctrine . . . $\$ 101$ The court also confirmed the doctrine's status as a rule of contract law, noting that mend the hold "expresse[s] and intend[s] something more with respect to the conduct of one who enters into a solemn written engagement and then repudiates it."102 Thus, the court grounded the doctrine in what is described today as the implied duty of good faith between contracting parties. ${ }^{103}$

Since then, Illinois courts have used mend the hold to limit contracting parties to positions taken during (not before) the litigation only. ${ }^{104} \mathrm{~A}$ party defending a refusal to perform must "stand

upon one good defense among others urged simply because he has not always put it forward, when it does not appear that he has acted dishonestly or that the other party has been misled to his harm, or that he is estopped on any other ground.").

${ }^{n 7}$ Gibson v Brown, 214 Ill 330, 341, 73 NE 578, 582 (1905). See also Schuyler County v Missouri Bridge and Iron Co, $256 \mathrm{Ill}$ 348, 352-53, $100 \mathrm{NE} \mathrm{239,} 240$ (1912).

* See, for example, Israel $v$ National Canada Corp, $276 \mathrm{Ill}$ App 3d 454, 462, 658 NE2d 1184,1191 (1996) ("Illinois law requires a defendant in a breach of contract claim to stand by the first defense raised after the litigation has begun. However, the law does not require that the defense be asserted at the time the contract is terminated.").

20 1 Ill App 2d 36, 116 NE2d 187 (1953).

${ }^{100} 116$ NE2d at 191 ("We have concluded from our examination of the cases that so far as the Illinois doctrine is concerned, it is not limited to equitable estoppel. The reviewing courts ... were familiar with the doctrine of equitable estoppel and there was no occasion for dressing it up with a subtitle.").

${ }^{101}$ Id at 192. In this respect Larson anticipated the UCC. See text accompanying notes 88-89.

102 Id at 191.

${ }^{100}$ Id at 191-92 (explaining that the rule stems from "the common practice among ... contracting parties ... to state a reason for repudiation," and thus "there are limitations upon its application"). See also Harbor Insurance, 922 F2d at 363 (explaining that "the doctrine ... can be seen as a corollary of the duty of good faith that the law of Hlinois as of other states imposes on the parties to contracts"), citing Larson, 116 NE2d at 191-92. Compare Smith, County Treasurer v German Insurance Co, 107 Mich 270, 279, 65 NW 236, 239 (1895) ("It is apparent that the ground, and the only ground, upon which all liability was denied, was the storage of gasoline ... . Good faith required that the [insurance] company should apprise the plaintiff fully of its position; and, failing to do this, it estops itself from asserting any defense other than that brought to the notice of plaintiff.").

${ }^{104}$ See, for example, IK Corp $v$ One Financial Place Partnership, 200 Ill App 3d 802, 815,558 NE2d 161, 170 (1990) ("IK contends that raising a new condition violates long established Illinois law. However, this is not a case where a party has switched his position 
by the first defense raised after the litigation has begun. ${ }^{.105}$ Litigation has "begun" once it has moved beyond the initial pleadings stage. ${ }^{106}$ The idea is to allow the defendant time to put together his defense ${ }^{107}$ but once that time is up, the duty of good faith between contracting parties requires the defendant to proffer all of his defenses or lose them forever. ${ }^{108}$

Whether the Illinois Supreme Court would approve of tying the doctrine to the duty of good faith is uncertain ${ }^{109}$ But in the face of that court's silence on the subject since 1912, the present understanding of the test in Illinois for an impermissible attempt to mend the hold is whether the change in litigation posture is made in good faith. ${ }^{110}$ Importantly, in this configuration, the Illinois version of mend the hold purports to do the same thing -at least once the litigation has begun-as the Texas and Massachusetts rule proscribing bad faith alterations to argument. However, because Texas and Massachusetts have no decisional law to illustrate the application of their bad faith test, this conclusion is not certain. ${ }^{111}$

at trial.") (emphasis added).

${ }^{105}$ Israel, 658 NE2d at 1191.

${ }^{106}$ Delaney $v$ Marchon, Inc, 254 Ill App 3d 933, 940-41, 627 NE2d 244, 249 (1993). But compare note 110.

${ }^{100}$ See Horwitz-Matthews, Inc $v$ City of Chicago, 78 F3d 1248, 1252 (7th Cir 1996).

${ }^{108}$ See Cleveland Hair Clinic, Inc v Puig, 949 F Supp 595, 600-01 (N D Ill 1996).

${ }^{109}$ The Delaney court relied on Judge Posner's opinion in Harbor Insurance as an authoritative exposition of the limits of mend the hold. Delaney, 627 NE2d at 249. In fact, the Harbor Insurance court was operating with a concession by the party seeking to employ the doctrine that sharply limited the doctrine's scope to avoid a head-on collision between the doctrine and the Federal Rules of Civil Procedure. 922 F2d at 364 ("It concedes that if pretrial discovery or other sources of new information justify a change in a contract party's litigating position as a matter of fair procedure under the federal rules, that change should not be deemed a forbidden attempt to mend the hold." $)$. Moreover, to the extent that the Delaney court justified its limitation of the doctrine to postpleading stage amendments because "no case law . . . clearly holds that the doctrine applies at the pleading stage," 627 NE2d at 239, the court was in error. In the Illinois Supreme Court's decision in Schuyler County, for example, the defendant won a county construction bid, but then announced by letter that it could not perform at the bid price, that the bid was a mistake. In the subsequent breach of contract action, the court limited the defendant to that explanation, which was made well before the litigation commenced. $100 \mathrm{NE}$ at 240 .

${ }^{110}$ Thus, in Horwitz-Matthews, an appeal from a dismissal below before the defendants had filed an answer, the Seventh Circuit opined that, even though the pleadings were not yet complete, "the 'mend the hold' doctrine" would not permit the defendant to change its position because it had "emphatically asserted[ed] its position" on appeal. $78 \mathrm{F3d}$ at 1252. See also Cleveland Hair Clinic, 949 F Supp at 601 (citing mend the hold as an alternative ground for refusing to allow a defense that the defendant had been aware of since the first pleadings).

${ }^{111}$ See note 96 and accompanying text. 


\section{FLEXIBLE FEDERAL PLEADING, THE ERIE DOCTRINE, AND THE APPLICATION OF MEND THE HOLD BY FEDERAL DIVERSITY COURTS}

Since the 1938 promulgation of the Federal Rules and Supreme Court decision in Erie Railroad Co $v$ Tompkins, ${ }^{112}$ federal courts sitting in diversity, while operating under the Federal Rules of Civil Procedure, apply the substantive law of the appropriate state. ${ }^{113}$ This Part explores whether the mend the hold doctrine is a substantive rule of law that federal diversity courts must enforce. The analysis involves two steps. The first is to determine whether any Federal Rule conflicts with mend the hold. If so, then the Federal Rule controls. ${ }^{114}$ The Federal Rules always trump conflicting state law regardless of whether the given state law is substantive or procedural. ${ }^{115}$ If there is no direct conflict, then the second step is to determine whether mend the hold is a substantive rule of law in light of Erie's twin aims of avoiding both forum shopping and an inequitable administration of the law. ${ }^{116}$

${ }^{112} 304$ US 64, 79-80 (1938) (holding that federal courts were bound by state common law in all cases in which they would be bound by state statutory law). See also S.A. Healy, 60 F3d at 309 (characterizing the promulgation of the Federal Rules of Civil Procedure and the Supreme Courts Erie decision as "the revolution in federalism of 1938 ").

${ }^{13}$ Hanna, 380 US at 465 . Choosing the appropriate state, however, is sometimes no easy task. See generally Wright, Miller, and Cooper, 19 Federal Practice and Procedure $\S$ 4506 (cited in note 13).

"Hanna, 380 US at 471 ("When a situation is covered by one of the Federal Rules, the question facing the court is a far cry from the typical, relatively unguided Erie choice: the court has been instructed to apply the Federal Rule, and can refuse to do so only if the Advisory Committee, this Court, and Congress erred in their prima facie judgment that the Rule in question transgresses neither the terms of the Enabling Act nor constitutional restrictions."); Trierweiler $v$ Croxton and Trench Holding Corp, 90 F3d 1523, 1539 (10th Cir 1996) ("The Supreme Court has continued to eschew the application of simple litmus tests in distinguishing between substantive and procedural law, except in one case: where a federal rule of procedure is directly on point, that rule applies."); Wright, Miller, and Cooper, 19 Federal Practice and Procedure $\$ 4511$ at 311-12 (cited in note 13) (explaining that there is no longer any significant Erie problem with regard to matters covered by the Federal Rules).

If the Federal Rule is not "a valid exercise of Congress" rulemaking authority," then of course it will not control. Burlington Northern Railroad Co $v$ Woods, 480 US 1, 5 (1987). But the Federal Rules enjoy "presumptive validity under both . . . constitutional and statutory constraints." Id at 6 . Thus, there is no real question about the validity of either of the Rules that could preempt mend the hold ( 8 and 15). The analysis below, therefore, focuses only on whether either Rule conflicts with the mend the hold doctrine.

${ }^{115}$ Burlington Northern, 480 US at 4-5; Hiatt v Mazda Motor Corp, 75 F3d 1252, 1259 (8th Cir 1996).

${ }^{116}$ Hanna, 380 US at 468; Fragoso v Lopez, 991 F2d 878, 881 (1st Cir 1993). 


\section{A. Does a Federal Rule Preempt Mend the Hold?}

Under the Federal Rules of Civil Procedure, the "pleadings kick off a course of pretrial discovery expected to result in modifications in the parties' positions. ${ }^{\text {p117 }}$ Mend the hold thus stands in stark contrast to the spirit of the Federal Rules, for application of mend the hold would rigidify "the system of pleading that the [Federal Rules] seek to make supple."118 The question, however, is whether there is a specific Federal Rule whose interpretation "is 'sufficiently broad' [as] to cause a 'direct collision' with" mend the hold, "thereby leaving no room for the operation of" the doctrine. ${ }^{119}$ The likeliest candidates are Rules 8 and 15.

\section{Rule 8.}

Rule 8(e)(2) permits parties to federal litigation to raise "as many separate claims or defenses as the party has regardless of consistency," subject only to the ethical commands of Rule $11 .{ }^{120}$ In contrast, the majority version of mend the hold limits a party's defenses to those based on the explanation for nonperformance given at the time of that nonperformance. The relevant determination is whether these rules can coexist, "each controlling its own intended sphere of coverage $\ldots .{ }^{121}$ An expansive reading of Rule 8 conflicts with mend the hold; ${ }^{122}$ the Rule explicitly permits all parties, including contract litigants, to state as many defenses as they wish.

The Supreme Court, however, has instructed courts construing the Federal Rules for these purposes to be sensitive to the state's interest in its rule. ${ }^{123}$ So a better interpretation is that

${ }^{117}$ Harbor Insurance, 922 F2d at 364.

${ }^{118} \mathrm{Id}$.

${ }^{119}$ Burlington Northern, 480 US at 4-5 (1987) (citations omitted). See also Wright, Miller, and Cooper, 19 Federal Practice and Procedure $\S 4510$ at 293 (cited in note 13) (explaining that "a precondition to the applicability of a Civil Rule in the face of contrary state law" is that "it must first be determined that the Rule, properly construed, truly comprehends the disputed issue and, therefore, is in conflict with state law").

${ }^{120}$ FRCP 8(e)(2). See also FRCP 11 (requiring parties to certify that their contentions are not baseless).

${ }^{121}$ Stewart Organization, Inc $v$ Ricoh Corp, 487 US 22, 31 (1988), quoting Walker $v$ Armco Steel Corp, 446 US 740, 752 (1980).

${ }^{12}$ See Nathan $v$ Boeing Co, 116 F3d 422, 424 (9th Cir 1997) (explaining that "we interpret federal law broadly when deciding if it conflicts with state law in an Erie situation"), citing Stewart Organization, 487 US at 31. But compare Eades $v$ Clark Distribution Co, Inc, 70 F3d 441, 443 (6th $\mathrm{Cir}$ 1995) (rejecting an argument that Stewart Organization compels a broad reading of the Federal Rules).

${ }^{123}$ Gasperini $v$ Center for Humanities, Inc, 518 US 415, 421 n 7 (1996). See J. Benjamin Jing, Note, Clarification and Disruption: The Effects of Gasperini v. Center for the Humanities, Inc. on the Erie Doctrine, 83 Cornell L Rev 161, 188-89, 193 (1997) ("If Gasperini 
Rule 8 permits litigants to raise any and all defenses that survive the mend the hold rule, regardless of their consistency. ${ }^{124}$ Unlike Burlington Northern Railroad Co $v$ Woods, ${ }^{125}$ where the Supreme Court held that a Federal Rule preempted state law because their operations and underlying purposes conflicted, the suggested interpretation gives effect to the policies animating both Rule 8 and mend the hold. After all, Rule 8 is designed "to liberate pleaders from the inhibiting requirement of technical consistency. ${ }^{p 126}$ Mend the hold, on the other hand, is concerned not with technical consistency between a party's various arguments, but with avoiding the lost opportunities to cure that result from the performing party's reliance on the nonperforming party's explanation. ${ }^{127}$ Thus, Rule 8 leaves room for the operation of mend the hold because the doctrine permits inconsistent pleadings; it only limits the universe of potentially inconsistent arguments to those based on the explanation given at the time of nomperformance. ${ }^{128}$

Rule 8 poses less of an obstacle to the minority version of mend the hold because it applies only to the pleadings. ${ }^{129}$ In contrast, the Illinois version of mend the hold only applies once the

indicates a turn in the Court's approach to the Erie doctrine, a Federal rule will apply in the face of a contrary state rule only when the Federal Rule sets an explicit standard leaving the courts little room for interpretation ...."). See also S.A. Healy Co, 60 F3d at 310-12 (holding that a state rule regarding settlement offers by plaintiffs is compatible with Rule 68's control over settlement offers by defendant), cited with approval in Gasperini, 518 US at 421 n 7; Richard H. Fallon, Daniel J. Meltzer, and David L. Shapiro, Hart and Wechsler's The Federal Courts and the Federal System 729-30 (Foundation 4th ed 1996) (noting that the Court continues to interpret the Federal Rules to avoid conflict with important state interests), cited with approval in Gasperini, 518 US at 437-38 n 22. Compare Stewart Organization, 487 US at 37-38 (Scalia dissenting) ("Thus, in deciding whether a federal procedural statute or Rule of Procedure encompasses a particular issue, a broad reading that would create significant disuniformity between state and federal courts should be avoided if the text permits.").

${ }^{124}$ Compare Trierweiler, 90 F3d at 1540 (interpreting Rule 11 so as to avoid a direct collision with a Colorado statute).

${ }^{125} 480$ US 1,7 (1987) ("Thus, the Rule's discretionary mode of operation unmistakably conflicts with the mandatory provision of Alabama's affirmance penalty statute. Moreover, the purposes underlying the Rule are sufficiently coextensive with the asserted purposes of the Alabama statue to indicate that the Rule occupies the statute's field of operation so as to preclude its application in federal diversity actions."). Compare Exxon Corp v Burglin, 42 F3d 948, 950 (5th Cir 1995) ('By allowing even minimal recovery of attorneys' fees in every civil appeal, Alaska Rule 508 directly collides with FRAP 38, which allows the recovery of attorneys' fees only in the case of a frivolous appeal.").

${ }^{12 x}$ Henry $v$ Daytop Village Inc, 42 F3d 89, 95 (2d Cir 1994), quoting Charles Alan Wright and Arthur R. Miller, 5 Federal Practice and Procedure: Civil $2 d \S 1282$ at 533 (West 2d ed 1990).

${ }^{127}$ See, for example, Nashville Marketplace Co, 1990 Tenn App LEXIS 212 at *16 ("Nashville Marketplace could have attempted to cure these problems before the expiration of the earn-out period had they been mentioned in the rejection notice.").

${ }^{123}$ See notes 119, 123 and accompanying text.

${ }^{12}$ FRCP 8. 
pleadings are complete. ${ }^{130}$ Thus, the two doctrines do not collide. Moreover, even if courts were to apply mend the hold to the pleadings stage, ${ }^{131}$ it still would not conflict with Rule 8 . The Illinois version of the doctrine does not purport to limit contracting parties' freedom to plead all of their claims or defenses regardless of consistency. ${ }^{132}$

Thus, neither the majority nor the minority version of the mend the hold doctrine conflict with Rule 8 to such an extent as to preempt the doctrine's application by federal diversity courts.

\section{Rule 15.}

Rule 15(a) provides that any party may amend its pleadings "by leave of court," which "leave shall be freely given when justice so requires."133 Therefore one can easily imagine a situation where the Rule appears to conflict with the majority version of mend the hold. A party to a contract might give an insufficient explanation for its nonperformance at the time of the breach. Then, during the course of discovery, this party learns of other facts that would have excused its nonperformance. By its terms, Rule 15 appears to allow the party to amend its pleadings to include the new defense-to mend its hold. Thus, if "justice requires" a court to hear the newly discovered defense, Rule 15 may preempt mend the hold. There is, however, an equally plausible interpretation of Rule 15-one that is more sensitive to the relevant state interests. Under this interpretation, a party to a breach of contract suit may seek leave to amend its pleadings to raise any issue except those lost by virtue of the mend the hold doctrine. The key to this interpretation is the term "justice." "Justice" can also be served by forbidding a party from mending its hold. ${ }^{134}$ Indeed, the judicial gloss on Rule 15 is consistent with the suggested interpretation: courts routinely reject amendments for,

${ }^{130}$ See Delaney $v$ Marchon, Inc, 254 Ill App 3d 933, 940-41, 627 NE2d 244, 249 (1993). The court in In re Apex Automotive Warehouse $L P$, avoided a conflict between Illinois mend the hold and the Federal Rules by refusing to apply the doctrine "at the pleading stage of a litigation." 205 Bankr 547, 554 (Bankr N D Ill 1997). The court's analysis has it backwards-Illinois's version of mend the hold does not apply at the pleadings stage and for that reason does not conflict with the Federal Rules-but the result is just the same.

${ }^{\text {is }}$ See, for example, Horwitz-Matthews $v$ City of Chicago, 78 F3d 1248, 1251-52 (7th Cir 1996) (explaining that, even though the pleadings were not yet complete, "the 'mend the hold' doctrine" would not permit the defendant to change its position because it had "emphatically assert[ed] its position" on appeal).

${ }^{132}$ IK Corp, 558 NE2d at 170.

${ }^{133}$ FRCP 15(a).

${ }^{14}$ See Wyoming Sawmills, Inc v Transportation Insurance Co, 282 Or 401, 578 P2d $1253,1257-58$ (1978) (In Banc) (describing mend the hold as "securely rooted in common justice"). 
among other reasons, bad faith and undue prejudice. ${ }^{135}$ Reading mend the hold into Rule 15's "justice" language retains liberal federal pleading while also giving effect to the states' mend the hold rule.

A recent Sixth Circuit decision illustrates the thrust of the suggested approach. ${ }^{136}$ The district court had excluded a defense based on "newly discovered evidence" on grounds other than the mend the hold doctrine. ${ }^{137}$ On appeal, the Sixth Circuit characterized the exclusion as "unjust under the facts and circumstances of this case." N138 Nevertheless, demonstrating how the Federal Rules and mend the hold could peaceably coexist, the court held that the defense could not be raised because "the law of Tennessee precludes" defendants from "justifying their conduct retroactively on a ground that is different from that which was proffered at the time of" nonperformance. ${ }^{139}$

Similar analysis reveals no direct conflict between Rule 15 and the minority version of mend the hold. At first it might ap-

${ }^{235}$ See Foman $v$ Davis, 371 US 178, 182 (1962) (holding that leave to amend should be "freely given" absent bad faith, undue prejudice, and certain other reasons); In re Southmark Corp, 88 F3d 311, 314-15 (5th Cir 1996) ("In deciding whether to grant . . . leave [to amend], the court may consider such factors as undue delay, bad faith or dilatory motive on the part of the movant, repeated failure to cure deficiencies by amendments previously allowed, undue prejudice to the opposing party, and futility of amendment."), citing Foman, 371 US at 182; Executive Leasing Corp v Banco Popular De Puerto Rico, 48 F3d 66, 71 (1st Cir 1995) ("Absent factors such as undue delay, bad faith, or dilatory motive, repeated failure to cure deficiencies by previous amendments, [or] undue prejudice to the opposing party, ... the leave [to amend] sought should be granted."), citing Foman, 371 US at 182; Garner v Kinnerar Manufacturing Co, 37 F3d 263, 269 (7th Cir 1994) ("While leave to amend should be freely given when justice requires, district courts have broad discretion to deny motions to amend in cases of undue delay, bad faith or dilatory motives, repeated failure to cure deficiencies by amendments previously allowed, undue prejudice or futility."); Fuller $v$ Secretary of Defense, 30 F3d 86, 88 (8th Cir 1994) (explaining that "[l]eave to amend should be granted absent a good reason for the denial, such as undue delay, bad faith, undue prejudice to the nonmoving party, or futility"). If justice excludes amendments in cases of bad faith, prejudice, dilatory motives, and so forth, why not add mend the hold to the list? Compare note 143 and accompanying text.

${ }^{130}$ Life Care Centers of America v Charles Town Associates Limited Partnership, LPIMC, Inc, 79 F3d 496, 508-09 (6th Cir 1996).

${ }^{13}$ Id.

${ }^{33 s}$ Id at 508.

${ }^{120}$ Id at 508-09. Although characterizing the rule as resting on "estoppel grounds," the court noted that the Tennessee rule represents an adoption of the McCarthy rule. Id at 508 \& $\mathrm{n}$ 9. This confusion stems from the use of the word estoppel in the McCarthy opinion: "He is not permitted thus to mend his hold. He is estopped from doing it by a settled principle of law." McCarthy, 96 US at 267-68 (emphasis added). Compare notes 18-22, 3334 and accompanying text. Notwithstanding this confusion, the rule that "once a contracting party has given reasons for its actions, it cannot attempt to justify its conduct on new and different grounds after suit is filed," Life Care Centers, 79 F3d at 508, quoting Nashville Marketplace, 1990 Tenn App LEXIS 212 at *16, is a manifestation of the mend the hold principle outlined in Part I. 
pear that by permitting changes in position only when those changes comport with the duty of good faith, the minority version of mend the hold operates in the same field as Rule 15(a). ${ }^{140}$ District courts, however, have wide latitude to deny leave to amend when the amendment is not proposed in good faith. ${ }^{141}$ Thus, Rule 15(a) and the minority version of mend the hold can be harmonized: the Rule does not require that federal district courts grant leave to amend when the amendment is an attempt to mend the hold, because by definition in Illinois an attempt to mend the hold is an amendment not made in good faith. ${ }^{142}$ Following this approach, in a case where a party sought leave to add a defense that it had been aware of since its original pleading, one district court fused Illinois mend the hold with Rule 15 to bar the amendment. ${ }^{143}$

In sum, Rule 8 and Rule 15 can peacefully coexist with both the majority and minority versions of the mend the hold doctrine. With no Federal Rule directly on point, even if mend the hold embodies "an antithetical conception of the litigation process" than the Federal Rules, ${ }^{144}$ the Rules pose no bar to applying mend the hold in federal court. ${ }^{145}$

\section{B. Is the Mend the Hold Doctrine Substantive or Procedural?}

The preemption analysis, however, resolves only half of the issue. The next question is whether mend the hold is a substantive rule of law that, under Erie, federal courts sitting in diversity

${ }^{140}$ See generally Stewart Organization, Inc v Ricoh Corp, 487 US 22, 31 (1988) (declining to apply Alabama law regarding forum selection clauses because 28 USC $\$ 1404$ (a) controlled the field); Burlington Northern, 480 US at $4-5$ (holding that FRCP 38 preempted an Alabama statute).

${ }^{141}$ See note 135.

${ }^{142}$ Although the Illinois amendment rule is similar to Rule 15, see 735 ILCS 5/2-616 (1996) ("At any time before final judgment amendments may be allowed on just and reasonable terms ...."), no Illinois court has raised it as a bar to mend the hold. This further supports the approach suggested above.

${ }^{143}$ See Mellon Bank, N.A. v Miglin, 1994 US Dist LEXIS 15439, *11-18 (N D Ill) (Adopted Magistrate's Opinion). See also Cleveland Hair Clinic, Inc v Puig, 949 F Supp 595,601 (N D Ill 1996) (citing mend the hold as an alternative ground for refusing to allow a defense that the defendant had been aware of since the first pleadings).

${ }^{14}$ Harbor Insurance, 922 F2d at 364.

${ }^{145}$ See Hanna, 380 US at 470 ("It is true that there have been cases where this Court has held applicable a state rule in the face of an argument that the situation was governed by one of the Federal Rules. But the holding of each such case was not that Erie commanded displacement of a Federal Rule by an inconsistent state rule, but rather that the scope of the Federal Rule was not as broad as the losing party urged, and therefore, there being no Federal Rule which covered the point in dispute, Erie commanded the enforcement of state law."). 
must respect. ${ }^{146}$ Even though the Supreme Court has refined the substance versus procedure inquiry over the years, ${ }^{147}$ it still can be "a challenging endeavor."148 Doctrines such as mend the hold (and judicial estoppel) that have both substantive and procedural dimensions resist categorical labels. ${ }^{149}$ If the rule channels the behavior of contracting parties outside the courtroom, it looks substantive. ${ }^{150}$ But if mend the hold merely controls what issues litigants may raise over the course of a case, it looks procedural. In the Supreme Court's most recent foray into the area, Gasperini $v$ Center for Humanities, Inc, ${ }^{151}$ the Court confirmed that the dis-

${ }^{146}$ See Erie, 304 US at 79-80; Trierweiler, 90 F3d at 1540 ("Because a Federal Rule is not directly on point, we move to the next step-the typical, relatively unguided Erie choice.").

${ }^{347}$ See, for example, Gasperini, 518 US at 426-31 (concluding that Erie commanded enforcement of a New York law limiting "excessive damages"); Stewart Organization, 487 US at 31 (concluding that 28 USC $\$ 1404$ occupies the field of forum selection clauses); Burlington Northern, 480 US at 4-5 (refining the rule of Hanna in cases where the Federal Rules conflict with state law); Walker $v$ Armco Steel Corp, 446 US 740, 752 (1980) (concluding that Rule 3 and Oklahoma's statute of limitations "can exist side by side"); Hanna, 380 US at 468 (tying the "outcome determination" test to "the twin aims of the Erie rule"); Byrd v Blue Ridge Rural Electric Cooperative, Inc, 356 US 525, 537-38 (1958) (employing a test balancing state and federal interests); Guaranty Trust Co $v$ York, 326 US 99, 109 (1945) (characterizing the Erie question as whether the state rule will "significantly affect the result of a litigation for a federal court to disregard a law of a State that would be controlling in an action upon the same claim by the same parties in a State court?"). But see Wright, Miller, and Cooper, 19 Federal Practice and Procedure $\$ 4504$ at 50 (cited in note 13) (explaining that "the Hanna opinion is the Supreme Court's last doctrinally significant contribution to the Erie doctrine").

${ }^{2 * 8}$ Gasperini, 518 US at 427.

${ }^{119}$ See Rissetto, 94 F3d at 602-04 (describing the disagreement among federal courts over whether judicial estoppel is substantive or procedural under Erie); Barron v Ford Motor Co of Canada, Ltd, 965 F2d 195, 199 (7th Cir 1992) (collecting doctrines, including mend the hold, that "mix procedural or evidentiary with substantive policy concerns"); Ashley S. Deeks, Comment, Raising the Cost of Lying: Rethinking Erie for Judicial Estoppel, $64 \mathrm{U}$ Chi L Rev 873, 884 (1997) (explaining that judicial estoppel "resists easy classification as either substantive or procedural").

${ }^{150}$ See Barron, 965 F2d at 199 (explaining that "a substantive rule is concerned with the channeling of behavior outside the courtroom ${ }^{n}$ ).

${ }^{261} 518$ US 415, 428 (1996) ("Informed by these decisions, we address the question whether [the state law in question] is outcome-affective in this sense: Would 'application of the [standard] . . . have so important an effect upon the fortunes of one or both of the litigants that failure to [apply] it would [unfairly discriminate against citizens of the forum State, or] be likely to cause a plaintiff to choose the federal court?"'), citing Hanna, 380 US at 468 (tying Guaranty Trust's "outcome determination" test to "the twin aims of the Erie rule"). See also Fragoso, 991 F2d at 881-82 (holding that a Puerto Rico rule was procedural because refusing to apply it in federal court would not "influence a litigant's choice of forum"; would not "advantage [federal plaintiffs] as compared with similarly situated, non-diverse plaintiffs"; and would not "bear in the slightest on the substantive outcome of the appeal"). Although Gasperini also considered whether the New York rule in question impinged on an "essential characteristic" of the federal courts, see 518 US at 431, quoting Byrd, 356 US at 537, this Comment ignores that question because the only potential conflicting federal interest, the Federal Rules, does not conflict with the doctrine, see Part II.A, whereas the state rule under consideration in Gasperini raised Seventh 
positive question is whether the state rule is outcome determinative when considered in light of Erie's twin aims of avoiding forum shopping and an inequitable administration of the laws.

\section{Erie and the majority (prelitigation) version of mend the hold.}

While the majority version of mend the hold presented a challenging analysis when deciding whether it conflicted with the Federal Rules, its treatment under traditional Erie twin aims analysis is less difficult. The doctrine, which by definition applies only to contracts cases, limits a party's defenses to those based on the explanation for nonperformance given at the time of that nonperformance or repudiation. Thus, as demonstrated by the modifications to the doctrine in insurance and brokerage contracts disputes ${ }^{152}$ mend the hold represents an effort to enforce certain substantive contract law policies. In other words, because it channels the prelitigation behavior of contracting parties, "the State's objective is manifestly substantive." ${ }^{\not 153}$

Put into more traditional Erie "twin aims" vernacular, this means that failing to apply the doctrine in federal court would lead both to an inequitable administration of the laws and to forum shopping, thus bringing mend the hold squarely within the substantive umbrella. First, a federal refusal to enforce mend the hold would lead to forum shopping because more defenses would be available in federal court than in state court. Depending on whether these defenses would be beneficial or not, parties will attempt to manipulate the choice of forum accordingly. ${ }^{154}$

Second, by offering a more extensive menu of potential defenses, federal courts would systematically advantage nonperforming parties. Therefore, a federal refusal to enforce the doc-

Amendment concerns, see 518 US at 432-36.

${ }^{152}$ See Part I.C.

${ }^{163}$ Gasperini, 518 US at 429, citing with approval S.A. Healy Co, 60 F3d at 310. In the words of the S.A. Healy court: "The second class of pretty easy cases is where the state procedural rule, though undeniably 'procedural' in the ordinary sense of the term, is limited to a particular substantive area, such as contract law .... For then the state's intention to influence substantive outcomes is manifest and would be defeated by allowing parties to shift their litigation into federal court unless the state's rule was applied there as well." Id at 310 (internal citations omitted).

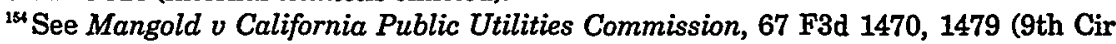
1995) (explaining that the availability of a multiplier for fees in state court, but not in federal court, would likely lead to forum-shopping"). Compare Fragoso, 991 F2d at 881 ("For one thing, it is inconceivable that a defendant's differential ability, depending upon whether the suit is brought in a federal or in a commonwealth court, to invoke Puerto Rico's procedural law anent insolvent insurers after trial and entry of judgment will influence a litigant's choice of forum."). 
trine would align behavioral incentives differently based only on the happenstance of diversity. The most frequently offered rationale for the mend the hold doctrine, after all, is to allow a contracting party to rely on the explanation for nonperformance given by the other party as exclusive. Thus, if a party wishes to save the deal, she may cure the cited defect with the assurance that the mend the hold doctrine will protect her from other reasons for nonperformance hidden in the background. ${ }^{155}$ But if federal courts refuse to enforce mend the hold, then contracting parties of diverse citizenship would proceed without the doctrine's protection from unmentioned problems. Such an inequitable administration of the law is not tolerable under the Erie doctrine. ${ }^{156}$

\section{Erie and the minority (postlitigation) version of mend the hold.}

The minority version of the rule becomes relevant only once litigation has begun. ${ }^{157}$ Even then it permits a party to change positions based on new information or other good faith reasons. ${ }^{158}$ Thus, a state's interest in the minority version of mend the hold is not as obviously substantive; the rule has a strong procedural flavor.

But the minority version applies during the litigation of contract disputes only, which suggests that it is a substantive rule. ${ }^{159}$

${ }^{165}$ See, for example, Nashville Marketplace Co, 1990 Tenn App LEXIS 212 at *16 ("Nashville Marketplace could have attempted to cure these problems before the expiration of the earn-out period had they been mentioned in the rejection notice."); Duclos, 6 $\mathrm{NE}$ at 790 ("No such objection was taken at the time by the defendants, and, had it been, the difficulty, no doubt, would have been obviated at once by the [broker].").

${ }^{166}$ See Mangold, 67 F3d at 1479 ("As this case illustrates, if a multiplier is procedural, a significant difference in fees would be available in state court but not in federal courtan inequitable administration of the law."). Compare Fragoso, 991 F2d at 881 ("For another thing, declining to apply the Commonwealth's procedural laws here will not advantage Fragoso as compared with similarly situated, nondiverse plaintiffs.").

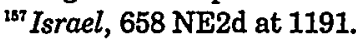

${ }^{158}$ Compare Cole Taylor Bank, 1994 US Dist LEXIS 3705 at *14-15 ("As pre-trial discovery revealed an alleged basis for the defenses of waiver and estoppel, this Court holds that application of the doctrine of 'mend the hold' to bar the Defendant's assertion of waiver and estoppel is not appropriate."), and Kafka $v$ Truck Insurance Exchange, 1992 US Dist LEXIS 9440, *8 (N D Ill) (explaining that mend the hold should not "bar meritorious contract defenses where the failure to raise those defenses early-on in litigation was merely inadvertent"), referring to Larson, 116 NE2d at 192, with Cleveland Hair Clinic, Inc v Puig, 949 F Supp 595, 601 (N D Ill 1996) (citing mend the hold as an alternative ground for refusing to allow a defense that the defendant had been aware of since the first pleadings), and Mellon Bank, 1994 US Dist LEXIS 15439 at *17-18 (Adopted Magistrate's Opinion) (denying a party leave to amend to add a defense that it had been aware of since its original pleading but had failed to raise).

${ }^{160}$ See S.A. Healy, $60 \mathrm{~F} 3 \mathrm{~d}$ at 310 ("The second class of pretty easy cases is where the state procedural rule, though undeniably 'procedural' in the ordinary sense of the term, is 
Its present incarnation, a corollary of the duty of good faith between contracting parties, represents a substantive choice by Illinois to treat litigants in contract disputes more strictly. Illinois expects "something more with respect to the conduct of one who enters into a solemn written engagement and then repudiates it." 160 Therefore, because the minority version of mend the hold is "Bound up with' the rights and obligations of" the parties, the "objectives of the Erie doctrine" militate in favor of applying the rule in federal court. ${ }^{161}$

Twin aims analysis, too, suggests that the Illinois version of mend the hold is substantive. First, a federal refusal to apply the doctrine could lead to forum shopping. Because a federal court would allow greater agility during the course of the litigation, nonperforming contracting parties would systematically choose federal court over state court. ${ }^{162}$ Second, permitting the happenstance of diversity to dictate whether the implied duty of good faith continues into the litigation context results in an inequitable administration of the laws. ${ }^{163}$ To be sure, the Illinois doctrine is less clearly a substantive rule of law than the majority version. Nonetheless, even the Illinois version of mend the hold advances a substantive policy-holding contracting parties to a higher standard. ${ }^{164}$ Therefore, without a conflicting federal policy, federal

limited to a particular substantive area, such as contract law .... For then the state's intention to influence outcomes is manifest and would be defeated by allowing parties to shift their litigation into federal court unless the state's rule was applied there as well.").

${ }^{160}$ Larson, 116 NE2d at 191 . See also text accompanying notes 99-103.

${ }^{161}$ Wright, Miller, and Cooper, 19 Federal Practice and Procedure $\S 4511$ at 313 (cited in note 13). See also Byrd v Blue Ridge Rural Electric Cooperative, Inc, 356 US 525, 53740 (1958) (balancing state and federal interests); Mayer v Gary Partners and Co, Ltd, 29 F3d 330, 333 (7th Cir 1994) ("The burden of persuasion is tied to the definition of the right, so state law determines whether the plaintiff must prove the case by a preponderance, by clear and convincing evidence, or by some other standard.").

${ }^{152}$ Compare Fragoso, 991 F2d at 881 ("For one thing, it is inconceivable that a defendant's differential ability, depending upon whether the suit is brought in a federal or in a commonwealth court, to invoke Puerto Rico's procedural law anent insolvent insurers after trial and entry of judgment will influence a litigant's choice of forum."), with Trierweiler, $90 \mathrm{~F} 3 \mathrm{~d}$ at 1541 ("A plaintiff alleging professional negligence is likely to seek a forum without the certificate of review hurdle either to avoid extra cost [or] to give himself more time to build a meritorious case ....”), and Mangold, 67 F3d at 1479 (explaining that "the availability of a multiplier for fees in state court, but not in federal court, would likely lead to forum-shopping"). See also S.A. Healy, 60 F3d at 312 ("The power of the state to jigger procedural rules to favor plaintiffs or defendants in federal diversity suits is limited [only] by the Rules Enabling Act and the Supremacy Clause....").

${ }^{11}$ See Trierweiler, $90 \mathrm{~F} 3 \mathrm{~d}$ at 1541 ("If the certificate of review requirement applies in state but not federal court, the inequitable result would be a penalty conferred on state plaintiffs but not on those in federal court under diversity jurisdiction."). But compare Wright, Miller, and Cooper, 19 Federal Practice and Procedure \$ 4511 at 8-9 (cited in note 13) (criticizing the reasoning, but not the result, of Trierweiler).

${ }^{18}$ See text accompanying note 160. 
courts sitting in diversity should enforce the Illinois version of mend the hold when Illinois law supplies the rule of decision.

\section{CONCLUSION}

Overlooked by modern contracts scholars, the mend the hold doctrine remains alive and well (although infrequently invoked) in a number of jurisdictions. In its majority version, the doctrine limits a contracting party's potential defenses to those based on the explanation for nonperformance asserted at the time of that nonperformance. In its minority formulation, mend the hold permits a contracting party to change its litigation position once the pleadings are complete only if that change comports with the implied duty of good faith.

The rule has mixed effects on incentives. On the one hand, it protects a party who wants to save the deal by ensuring that the other party will not raise other impediments to performance later on. On the other hand, strategically minded parties who refuse to perform will simply reserve all their defenses by refusing to give any explanation at all. Thus, it is not clear that embracing an absolutist version of the majority rule is good policy. Whether a rule is good or bad policy, however, has no bearing on whether it should control in federal diversity actions. Without a Federal Rule to preempt the doctrine's operation, and because Erie twin aims analysis suggests that mend the hold is a substantive rule of law, mend the hold represents the sort of state prerogative that federal courts sitting in diversity must respect. 


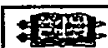

(nsing

追的 